\title{
MURABAHAH ANTARA LAWFULL DAN DOUBTHFULL (Analisis Produk Murabahah di KSU Sejahtera UMP)
}

\author{
Oleh : Ida Nurlaeli dan Mintaraga Eman Surya
}

Fakultas Ekonomi dan Bisnis Islam Universitas Islam Negeri Walisongo dan Universitas Muhammadiyah Purwokerto

Email : idanurlaeli_1326@yahoo.com, dan albiologysy@yahoo.com

\begin{abstract}
Abstrak
Dalam pembahasan tentang kesyar'ian produk lembaga keuangan syari'ah, produk Murabahah menjadi suatu produk yang selalu diragukan kesyar'iannya. Maka artikel hasil penelitian ini bertujuan untuk memperoleh gambaran tentang bagaimana penerapan produk Murabahah di Lembaga Keuangan Syari'ah dengan mengambil sampel produk murabahah di KSU Sejahtera UMP (Universitas Muhammadiyah Purwokerto). Artikel ini dari hasil penelitian dengan menggunakan pendekatan kualitatif. Sedangkan teknik pengumpulan data menggunakan wawancara, observasi, dokumentasi. Analisis data menggunakan deskriptif analisis dengan melalui tiga prosedur yaitu reduksi data, penyajian data dan penarikan kesimpulan. Dari data-data yang diperoleh kemudian dianalisis secara kualitatif, yakni menganalisis dari sisi teknis/aksiologis, yakni pelaksanaan produk Murabahah di KSU Sejahtera UMP telah memenuhi kriteria syar'i atau belum. Selama ini teknis murabahah yang ada di KSU Sejahtera UMP yakni KSU telah memposisikan lembaganya sebagai penjual, meskipun tidak menyediakan secara langsung barang-barang tersebut ditempat, namun KSU Sejahtera telah menjalin kerjasama dengan beberapa penyedia barangbarang yang dibutuhkan nasabah.
\end{abstract}

\section{Abstract}

In the discussion about product Shari'ah financial institutions, Murabaha product into a product that is always in doubt syar'i. Then the article the results of this study aims to gain an overview of how the application of Murabaha product in KSU Sejabtera UMP. Is it in accordance with the provisions of Shari'ah in terms of both technical/ hakikatnya. Artikel axiological and in terms of the results of this study using a qualitative approach. While data collection techniques using interviens, observation, documentation. Analysis of the data using descriptive analysis through three procedures of data reduction, data display and conclusion. From the data obtained and analyzed 
qualitatively. The results showed that technically/axiological, Murababa product implementation at KSU Sejabtera Sharai UMP has met the criteria. For example KSU Sejabtera UMP has positioned the institution as a seller, though not directly provide these items in place but KSU Welfare has established cooperation with several providers of goods required by customers.

Key Word: Murabahah; syar'i; syari'ah; nasabah.

\section{A. Pendahuluan}

Pada penelitian sebelumnya yang berjudul "Studi Analisis Sikap MES (Masyarakat Ekonomi Syari'ah) terhadap Produk-produk Perbankan Syari'ah dengan Pendekatan Kaidah-kaidah Fiqhiyah" peneliti memperoleh suatu kesimpulan bahwa; sikap masyarakat khususnya MES (Masyarakat Ekonomi Syari'ah) ternyata didominasi oleh keraguankeraguan akan kesyar'ian produk-produk Bank Syari'ah. Hal ini dibuktikan dengan beragamnya pendapat yang muncul tentang produk-produk yang ada di Bank Syariah. Pendapat tersebut terpecah menjadi 3 (tiga) antara lain unlawfull; yang berpendapat bahwa produk-produk di Bank Syari'ah tidak syar'i, doubthfull; yang berpendapat bahwa produk-produk di Bank Syari'ah baru setengah syar'i dan lawfull; yang berpendapat bahwa produkproduk di Bank Syari'ah sudah syar'i.

Berkaitan dengan produk murabahah, dari penelitian yang pernah peneliti lakukan sebelumnya, prosentase terbesar berpendapat bahwa produk tersebut masih setengah syar'i atau belum sempurna pelaksanaannya. Dari 3 (tiga) macam pendapat yang muncul, $30 \%$ mengatakan produk murabahah di Bank Syari'ah sudah syar'i, 50\% mengatakan setengah syar'i, dan $20 \%$ mengatakan tidak syar'i. ${ }^{2}$ Hal ini terlepas dari tingkat pengetahuan responden terhadap produk-produk Bank Syari'ah.

Dari keadaan tersebut peneliti ingin menganalisis kesyar'ian produk Murobahah tersebut, dimana produk Murobahah-lah yang seolah menjadi momok bahwa Lembaga Keuangan Syari'ah sama saja dengan

\footnotetext{
1 Penelitian tahun 2011 Dibiayai oleh Lembaga Penelitian dan Pengabdian pada Masyarakat Universitas Muhammadiyah Purwokerto sesuai dengan Surat Perjanjian Pelaksanaan Penelitian Nomor : A.11-III/097S.Pj./LPPM/IV/2013

${ }^{2}$ Hasil Penelitian Ida Nurlaeli, Mintaraga Eman Surya, 2012, Studi Analisis Sikap MES (Masyarakat Ekonomi Syari'ah) Terhadap Produk-produk Bank Syari'ah Dengan Pendekatan Kaidah-kaidah Fiqhiyah.
} 
Lembaga Keuangan Konvensional. Hal ini didukung karena dugaan kurang sempurnanya Lembaga Keuangan Syari'ah dalam mempraktekkan produk Murobahah, sehingga yang menjadi target peneliti adalah memperoleh keterangan yang jelas dari Lembaga Keuangan Syari'ah tentang cara pelaksanaan/praktek produk Murobahah tersebut. Untuk memperolehnya peneliti akan mengadakan wawancara terhadap pengambil kebijakan, pegawai yang melayani pengambilan produk Murobahah dan nasabah yang mengambil produk Murobahah dalam sebuah Lembaga Keuangan Syari'ah. Dalam hal ini Lembaga Keuangan Syari'ah yang dijadikan sampel oleh peneliti adalah KSU Sejahtera UMP. Selanjutnya data-data yang diperoleh dari KSU Sejahtera UMP tersebut, akan peneliti bandingkan dengan pelaksanaan produk Murobahah yang sebenarnya dalam Ekonomi Islam atau yang seharusnya dilaksanakan.

\section{B. Murabahah Dalam Ekonomi Islam}

Dalam bukunya, Cecep Maskanul Hakim memaparkan tentang problematika penerapan murabahah dalam Bank Syari'ah, diskon dalam murabahah, dan sanksi-sanksi dalam kegiatan operasionalnya apabila ada pelanggaran. Menurut Cecep Maskanul Hakim, Murabahah yang dikenal dalam syari'ah sebagai transaksi mengalami inovasi ketika diterapkan dalam perbankan syari'ah. Hal ini disebabkan berbagai ketentuan yang ada, selain ketentuan perbankan, juga belum mengakomodir sifat-sifat yang ada dalam Murabahah, baik ketentuan hokum maupun perpajakan. Usaha ini memerlukan pengertian dan pemahaman semua pihak tentang manfaat dan keunggulan transaksi ini disbanding transaksi dalam perbankan konvensional. Apabila tidak demikian, maka keunggulan dan manfaat perbankan syari'ah bagi masyarakat dan ekonomi nasional jadi tidak nampak. ${ }^{3}$

Pengertian murabahah sendiri, sudah banyak sekali pakar ekonomi Islam yang membahasnya, diantaranya Muhammad Ibn Ahmad Ibnu Muhammad Ibn Rusyd, yang mengatakan bahwa Bäi al murabahab adalah jual beli barang pada harga asalnya dengan tambahan keuntungan yang disepakati. ${ }^{4}$

\footnotetext{
${ }^{3}$ Cecep Maskanul Hakim, 2011, Belajar Mudah Ekonomi Islam, Catatan Kritis Terhadap Dinamika Perkembangan Perbankan Syari'ah di Indonesia, Banten, Shuhuf Media Insani, h. 80

${ }^{4}$ Muhammad Ibn Ahmad Ibnu Muhammad Ibn Rusyd, Bidayatul Mujtahid wa Nihayatul Muqtasyid Darul Qalam, , vol II, Beirut, h. 216
} 
Sedangkan tujuan Murabahah menurut Muhammad syafi'i Antonio, tampaknya berakar pada dua alasan yakni: Pertama, mencari pengalaman. Satu pihak yang berkontrak (pemesan pembelian) meminta pihak lain (pembeli) untuk membeli sebuah asset. Pemesan berjanji untuk ganti membeli asset tersebut dan memberinya keuntungan. Pemesan memilih system pembelian ini yang biasanya dilakukan secara kredit, lebih karena ingin mencari informasi disbanding alas an kebutuhan yang mendesak terhadap asset tersebut. Kedua, mencari pembiayaan. Dalam operasi perbankan syari'ah, motif pemenuhan pengadaan asset atau modal kerja merupakan alas an utama yang mendorong dating ke bank. Pada gilirannya pembiayaan yang diberikan akan membantu memperlancar arus kas (cash flow) yang bersangkutan. ${ }^{5}$

Murabahah adalah bentuk pembiayaan dengan prinsip jual beli barang yang telah ada, dengan menentukan harga jual dari harga perolehan ditambah margin yang telah disepakati bersama.

Dalam Pasal 1 angka 7 Peraturan Bank Indonesia No. 7/46/PBI/2005 tentang Akad Penghimpunan dan Penyaluran Dana Bagi Bank yang Melaksanakan Kegiatan Usaha Berdasarkan Prinsip Syariah, pengertian Murabahah adalah jual beli barang sebesar harga pokok barang ditambah dengan margin keuntungan yang disepakati.

Sedangkan dalam pasal 20 angka 6 Peraturan Mahkamah Agung No. 02 Tahun 2008 tentang Kompilasi Hukum Ekonomi Syariah), Murabahah adalah pembiayaan saling menguntungkan yang dilakukan oleh shahib almal (pemilik modal) dengan pihak yang membutuhkan melalui transaksi jual beli dengan penjelasan bahwa harga pengadaan barang dan harga jual terdapat nilai lebih yang merupakan keuntungan atau laba bagi shahib almal dan pengembaliannya dilakukan secara tunai atau angsur.

Mengenai utang dalam Murabahah, ketentuan Bagian Keempat Fatwa Dewan Syariah Nasional Majelis Ulama Indonesia (DSN-MUI) No. 04/DSN-MUI/IV/2000 tentang Murabahah (sumber www.mui.or.id), mengatur sebagai berikut: (1) Secara prinsip, penyelesaian utang nasabah dalam transaksi murabahah tidak ada kaitannya dengan transaksi lain yang dilakukan nasabah dengan pihak ketiga atas barang tersebut. Jika nasabah

\footnotetext{
${ }^{5}$ Muhammad Syafi'i Antonio, 2001, Bank Syari'ah dari Teori ke Praktik, Jakarta, Gema Insani, h. 102
} 
menjual kembali barang tersebut dengan keuntungan atau kerugian, ia tetap berkewajiban untuk menyelesaikan utangnya kepada bank, (2) Jika nasabah menjual barang tersebut sebelum masa angsuran berakhir, ia tidak wajib segera melunasi seluruh angsurannya, (3) Jika penjualan barang tersebut menyebabkan kerugian, nasabah tetap harus menyelesaikan utangnya sesuai kesepakatan awal. Ia tidak boleh memperlambat pembayaran angsuran atau meminta kerugian itu diperhitungkan.

Dalam buku Akad Syariah, Devita Purnamasari, S.H., M.Kn, menjelaskan antara lain bahwa sebagai salah satu rukun akad, objek dalam murabahah yaitu barang yang dijual harus secara prinsip sudah beralih kepemilikannya ke tangan penjual (hal. 45). Jadi, berdasarkan uraian tersebut, dapat kita ketahui bahwa dalam murabahah barang yang dijual harus secara prinsip sudah beralih kepemilikannya ke tangan penjual. Karena itu, nasabah dapat secara bebas menjual barang (objek) perjanjian murabahah, walaupun belum dilunasi pembayarannya.

Antara pembiayaan Murabahah dan pembiayaan pada umumnya atau pembiayaan konvensional sebenarnya terdapat perbedaan yang jelas, sebagaimana telah disebutkan dalam tinjauan pustaka, yakni sebagai berikut:

Tabel. B.2.

Perbedaan jual beli sistem Murabahah dengan sistem Riba

\begin{tabular}{|l|l|l|}
\hline No & Jual beli system Murabahah & \multicolumn{1}{c|}{ Sistem Bunga/riba } \\
\hline 1 & $\begin{array}{l}\text { Barang sebagai obyek, } \\
\text { nasabah berhutang barang, } \\
\text { bukan berhutang uang }\end{array}$ & $\begin{array}{l}\text { Uang sebagai obyek, nasabah } \\
\text { berhutang uang }\end{array}$ \\
\hline 2 & $\begin{array}{l}\text { Sektor moneter terkait } \\
\text { dengan sector riil, sehingga } \\
\text { menyentuh langsung sector } \\
\text { riil }\end{array}$ & $\begin{array}{l}\text { Sektor moneter dan riil terpisah, } \\
\text { tidak ada keharusan mengaitkan } \\
\text { sector moneter dan riil }\end{array}$ \\
\hline 3 & $\begin{array}{l}\text { Mendorong percepatan arus } \\
\text { barang, mendorong } \\
\text { produktivitas dan } \\
\text { entrepreneurship, yang pada } \\
\text { gilirannya meningkatkan } \\
\text { employment }\end{array}$ & $\begin{array}{l}\text { Tidak mendorong percepatan } \\
\text { arus barang, karena tidak } \\
\text { mewajibkan adanya barang, } \\
\text { tidak mendorong produktivitas } \\
\text { yang pada akhirnya menciptakan } \\
\text { unemployment }\end{array}$ \\
\hline
\end{tabular}




\begin{tabular}{|c|c|c|}
\hline 4 & $\begin{array}{l}\text { Pertukaran barang dengan } \\
\text { uang }\end{array}$ & Pertukaran uang dengan uang \\
\hline 5 & Margin tidak berubah & $\begin{array}{l}\text { Bunga berubah sesuai tingkat } \\
\text { bunga }\end{array}$ \\
\hline 6 & $\begin{array}{l}\text { Akad jual beli dan memenuhi } \\
\text { rukun jual beli }\end{array}$ & $\begin{array}{l}\text { Tidak ada akad jual beli, tetapi } \\
\text { uang langsung sebagai } \\
\text { komoditas }\end{array}$ \\
\hline 7 & $\begin{array}{l}\text { Bila macet, tidak ada bunga } \\
\text { berbunga }\end{array}$ & Terjadi compound interest \\
\hline 8 & $\begin{array}{l}\text { Jika nasabah tidak mampu } \\
\text { membayar, tidak ada denda } \\
\text { (QS. 2: 283) }\end{array}$ & Denda/bunga \\
\hline 9 & $\begin{array}{l}\text { Jika nasabah dinilai mampu, } \\
\text { tetapi tidak bayar, dikenakan } \\
\text { denda untuk mendidik. } \\
\text { Dananya untuk social bukan } \\
\text { pendapatan bank }\end{array}$ & $\begin{array}{l}\text { Denda/bunga berbunga } \\
\text { cenderung } \\
\text { menzalimi/eksploitasi, tidak } \\
\text { mendidik dan denda bunga } \\
\text { menjadi pendapatan bank }\end{array}$ \\
\hline 10 & $\begin{array}{l}\text { Terjadi pemindahan } \\
\text { kepemilikan, barang sekaligus } \\
\text { sebagai jaminan }\end{array}$ & $\begin{array}{l}\text { Tidak ada pemindahan } \\
\text { kepemilikan }\end{array}$ \\
\hline 11 & $\begin{array}{l}\text { Tidak membuka jalan } \\
\text { spekulasi }\end{array}$ & $\begin{array}{l}\text { Bunga membuka } \\
\text { peluang/menjadi lahan spekulasi }\end{array}$ \\
\hline 12 & Sah, halal, dan penuh berkah & $\begin{array}{l}\text { Tidak sah, haram, dan jauh dari } \\
\text { berkah serta mendapat laknat }\end{array}$ \\
\hline 14 & $\begin{array}{l}\text { Uang sebagai alat tukar } \\
\text { (purchasing power) }\end{array}$ & $\begin{array}{l}\text { Over supply of money (inflasi dan } \\
\text { devaluasi) }^{6}\end{array}$ \\
\hline
\end{tabular}

Sedangkan menurut peneliti sendiri, ciri dari Murabahah yakni suatu transaksi dimana pihak pemilik modal (lembaga keuangan) memposisikan dirinya sebagai penjual dan peminjam modal (nasabah) berada pada posisi sebagai pembeli. Dalam kegiatan jual beli itu sendiri, barang yang dijual haruslah sudah menjadi milik penuh dari penjual sehingga tidak diperbolehkan menjual barang yang bukan miliknya, selanjutnya ada kesepakatan harga antara kedua belah pihak yang bertransaksi.

\footnotetext{
${ }^{6}$ Nurul Huda, Mohamad Heykal, 2010, Lembaga Keuangan Islam, Tinjauan Teoritis dan Praktis, Jakarta, Kencana, h. 45
} 
Dalam jual beli, barang harus terganti dengan uang, jadi bukan uang terganti dengan uang. Dalam hal ini ketika nasabah tidak memiliki uang dan dia membutuhkan barang maka pemilik modal (lembaga keuangan) harus memberikannya barang. Tidak dibenarkan memberi nasabah uang kemudian nasabah berkewajiban mengembalikannya dengan beberapa uang tambahan (anakan).

\section{Metode Penelitian}

Penelitian ini diawali dengan field research/penelitian lapangan, ${ }^{7}$ yang berguna untuk mengumpulkan data, setelah data terkumpul dilanjutkan library research/penelitian pustaka yakni menganalisis data yang sudah ditemukan dengan sumber-sumber pustaka.

a. Ruang lingkup Penelitian

Ruang lingkup penelitian ini meliputi Koperasi antara lain terdiri dari pengambil kebijakan dalam koperasi, ketua dan pengurus koperasi, pegawai dan beberapa nasabah. ${ }^{8}$ Dalam hal ini peneliti mengambil KSU Sejahtera UMP sebagai sampel.

b. Jenis dan Sumber Data

Jenis data yang dikumpulkan adalah yang berkaitan dengan jenis dan praktek penerapan produk Murabahah yang ada di KSU Sejahtera UMP. Melalui informan terpilih akan dikumpulkan informasi mengenai masalah yang diteliti. Data yang diperoleh ini merupakan data primer karena sangat berpengaruh pada analisis data.

Sumber yang akan dijadikan rujukan adalah para informan tersebut. Orang yang akan dijadikan informan atau sumber data adalah pengambil kebijakan di KSU Sejahtera UMP, ketua dan pengurus atau pegawai serta beberapa nasabah yang mengambil produk Murobahah di KSU Sejahtera UMP.

c. Teknik Pengumpulan Data

Jenis data yang dikumpulkan adalah yang berhubungan dengan jenis produk dan praktek penerapannya, maka teknik yang sesuai adalah dengan wawancara terstruktur dan wawancara mendalam.

${ }^{7}$ Koentjaraningrat, 1998, Metode-metode Penelitian Masyarakat, Jakarta, Gramedia Utama, hal. 129

8 Pengambilan nasabah sebagai responden melalui pemilihan, yakni nasabah di KSU Sejahtera UMP yang mengambil produk Murabahah dan mempunyai kemampuan untuk dimintai data dengan memperhatikan kemampuan bicara dan tingkat pendidikan nasabah 
Pelaksanaan wawancara mendalam (dept interview) dilakukan dengan penguasaan pokok persoalan oleh peneliti. Wawancara terstruktur dilakukan pada waktu studi lapangan lanjutan. Pada waktu inipun masih ada kesempatan untuk probing yakni pengejaran data lebih mendalam.

d. Teknik Analisis Data

Penelitian ini adalah penelitian lapangan yang bersifat deskriptif, dimana prosedur pemecahan yang diselidiki dengan menggambarkan dan melukiskan keadaan subyek dan obyek penelitian pada saat sekarang berdasarkan fakta-fakta yang tampak sebagaimana adanya.

Model Analisis data apabila telah terkumpul dengan analisis kualitatif, yaitu analisis terhadap data yang bersifat kualitatif yaitu data yang digambarkan dengan kata-kata atau kalimat-kalimat yang dianalisis untuk memperoleh kesimpulan.

Dalam hal ini pendekatan yang diperlukan adalah pendekatan tafsir ayat-ayat tentang murabahah dan pemahaman terhadap ketentuanketentuan murabahah dalam Ekonomi Islam, sangat dibutuhkan yakni untuk menentukan kesyar'ian produk murabahah yang sudah dipraktekkan di KSU Sejahtera UMP.

Sumber-sumber sebagai referensi untuk menganalisis data disamping ayat-ayat Al Qur'an dan Hadits yang membahas tentang muamalah khususnya tentang produk-produk koperasi syari'ah, buku-buku yang berkaitan dengan masalah-masalah dan ketentuan-ketentuan hukum islamnya, antara lain Fikih Kontemporer, Ushul Fikih, Masail Fiqhiyah, Al Asybah Wa Al Nadzair dan sebagainya, dan buku-buku ekonomi syari'ah lainnya.

\section{Murabahah di KSU Sejahtera UMP, Antara Lawfull dan Doubthfull}

KSU Sejahtera UMP termasuk di dalamnya BTM Sejahtera UMP merupakan lembaga keuangan syari'ah, pada umumnya kegiatan operasional yang dilakukan oleh lembaga keuangan syari'ah dapat dibagi ke dalam tiga bagian besar. Tiga bagian itu berkaitan dengan produk yang ada dalam dunia perbankan Islam. Lebih lanjut pengelompokkan tersebut sebagai berikut: 
Tabel.B.1. Kegiatan operasional perbankan Islam

\begin{tabular}{|l|l|l|}
\hline $\begin{array}{c}\text { Penghimpunan } \\
\text { Dana }\end{array}$ & \multicolumn{1}{|c|}{ Penyaluran Dana } & $\begin{array}{l}\text { Jasa-jasa Lembaga } \\
\text { Keuangan Syariah }\end{array}$ \\
\hline 1. Wadiah & 1. Piutang & Rahn \\
\hline 1.1 Giri & 1.2 Qardh & Wakalah \\
\hline 1.2 Tabungan & 1.3 Murabahah & Kafalah \\
\hline 2. Mudarabah & 1.4 Salam & Hawalah \\
\hline 2.1 Tabungan & 1.5 Istishna & Sharf \\
\hline 2.2 Deposito & 2. Investasi & \\
\hline & $\begin{array}{c}\text { 2.1. Mudarabah: } \\
\text { 2.1.1. Mutlaqah } \\
\text { 2.1.2. Muqayyadah }\end{array}$ & \\
\hline & 2.2. Musyarakah & \\
\hline & 3. Sewa & \\
\hline & 3.1 Ijarah & \\
\hline & Bittamlik ${ }^{9}$ & \\
\hline
\end{tabular}

Berdasarkan ketentuan-ketentuan tentang Murabahah di atas, peneliti akan menganalisis pelaksanaan produk Murabahah di KSU Sejahtera UMP. Setelah peneliti mengadakan wawancara kepada pegawai di KSU Sejahtera UMP di dapatkan informasi, pelaksanaan produk Murabahah di KSU Sejahtera UMP sebagaimana mekanisme berikut:

1. Seorang nasabah menginginkan sebuah barang lalu mengajukan permohonan dana ke Lembaga Keuangan Syariah (KSU Sejahtera UMP).

2. Pihak KSU Sejahtera UMP akan meninjau kelayakan nasabah meliputi pendapatannya, kebutuhannya, tanggungannya dan sisa pendapatannya (pendapatan bersih). Maka pihak pemilik modal hanya akan membelikan barang jika sesuai dengan kelayakannya dimana pendapatan bersih tersebut menjadi acuannya. Perbedaan antara pembiayaan Murabahah dengan pembiayaan sistem bunga mulai nampak dalam tahap ini, karena dalam pembiayaan sistem bunga pemilik modal selalu mengabulkan berapapun besarnya dana yang

\footnotetext{
${ }^{9}$ Nurul Huda Mohammad Heykal, h. 40
} 
diminta oleh nasabah tanpa meninjau kelayakan atau penghasilan dari nasabah.

3. Selanjutnya pemilik modal (KSU Sejahtera UMP) merekomendasikan agar nasabah mengambil barang yang diinginkan di tempat (dealer, toko, distributor) yang mempunyai hubungan kerjasama dengan KSU Sejahtera UMP. Dalam hal ini tidak selamanya barang yang dikehendaki oleh nasabah harus ada di sebuah lembaga keuangan syari'ah, tetapi dengan menjalin kerjasama dengan pihak lain (toko, dealer, distributor) sudah bermakna pemilik modal telah memposisikan dirinya sebagai penjual, karena ada akad kerjasama sebelumnya.

4. Akad. Dalam pembiayaan system Murabahah terdapat akad sedangkan dalam pembiayaan system bunga tidak terdapat akad.

5. Pemilik modal (KSU Sejahtera UMP) membayarkan uang ke toko, dealer, distributor yang barangnya dibeli oleh nasabah. Hal ini berbeda dengan pembiayaan system bunga, dimana dalam pembiayaan system bunga pemilik modal langsung memberikan uang pembayaran barang tersebut kepada nasabah, dan pemilik modal tidak bisa mendeteksi apakah uang tersebut digunakan untuk membeli barang yang yang direncanakan atau tidak, sehingga dapat menimbulkan pembelanjaan barang yang sebenarnya tidak dibutuhkan, tetapi hanya untuk memenuhi kebutuhan kemewahan.

Seandainya teknis tersebut sudah benar-benar dijalankan oleh KSU Sejahtera UMP maupun lembaga keuangan syari'ah yang lain, sebenarnya menurut peneliti hal tersebut sudah memenuhi batas syar'i. Namun tidak menutup kemungkinan ada beberapa pendapat yang mengatakan kesyar'ian itu bukan hanya dari teknisnya saja tetapi seberapa jauh teknis tersebut memberikan maslahah/manfaat yang besar bagi nasabah yang membutuhkan. Sehingga dalam produk-produk lembaga keuangan syari'ah seharusnya "yang dianggap syar'i adalah hakikatnya juga, bukan hanya bahasa (istilah) nya"

Syar'i secara teknis merupakan bagian pertanggungjawaban dalam memenuhi ketentuan syari'at Islam, Al Baqarah ayat 42: "Dan janganlah kamu campur adukkan yang hak dengan yang bathil dan janganlah kamu sembunyikan yang hak itu, sedang kamu mengetahui". QS Ali Imran ayat 71: "Hai Ahli Kitab, mengapa kamu mencampur adukkan yang haq 
dengan yang bathil, dan menyembunyikan kebenaran, padahal kamu mengetahuinya?".

Sedangkan syar'i secara hakikat merupakan bagian dari bablumminannas, bagaimana lembaga keuangan syari'ah mempunyai misi membantu, melayani dan memudahkan kebutuhan nasabah, dalam QS Al Qashash ayat 77: "Dan carilah pada apa yang telah dianugerahkan Allah kepadamu (kebahagiaan) negeri akhirat, dan janganlah kamu melupakan bahagianmu dari (kenikmatan) duniawi dan berbuat baiklah (kepada orang lain) sebagaimana Allah telah berbuat baik, kepadamu, dan janganlah kamu berbuat kerusakan di (muka) bumi. Sesungguhnya Allah tidak menyukai orang-orang yang berbuat kerusakan"

\section{E. Kesimpulan}

Dari hasil pembahasan di atas dapat disimpulkan bahwa pembiayaan sistem Murabahah yang dijalankan oleh KSU Sejahtera secara teknis sudah memenuhi kriteria syar'i, namun peneliti belum sampai pada tahap penelitian dari segi hakikatnya, seperti seberapa besar nasabah dapat mengambil manfaat dari produk Murabahah yang diambil tersebut, apakah produk Murabahah benar-benar sudah bisa menjadi solusi atas kebutuhan akan barang bagi nasabah, atau berapa besar prosentase margin yang ditentukan oleh pihak lembaga keuangan syari'ah (KSU Sejahtera UMP).

Sebagai produk syari'ah, Murabahah memang harus diusahakan tidak hanya syar'i secara teknis tetapi syar'i pula dari segi hakikatnya. Contohnya margin yang ditentukan tidak lebih tinggi dari pembiayaan konvensional yang lain, administrasinya tidak merepotkan, meskipun sebenarnya karena kita muslim maka bertransaksi dengan lembaga keuangan syari'ah sudah menjadi suatu keharusan. Namun akan lebih baik lembaga keuangan syari'ah dapat memberikan dua kesyar'ian tersebut, syar'i dari segi teknis dan syar'i dari segi hakikat. Seandainya hal tersebut dapat diwujudkan maka tidak ada kekhawatiran terhadap perkembangan ekonomi Islam karena dapat bersaing dengan lembaga keuangan konvensional dan mampu memperoleh kepercayaan dari nasabah sebagai lembaga keuangan yang benar-benar mampu memberikan solusi atas kebutuhan nasabah. 


\section{DAFTAR PUSTAKA}

Cecep Maskanul Hakim, 2011, Belajar Mudah Ekonomi Islam, Catatan Kritis

Terhadap Dinamika Perkembangan Perbankan Syari'ah di Indonesia, Banten, Shuhuf Media Insani

Koentjaraningrat, 1998, Metode-metode Penelitian Masyarakat, Jakarta, Gramedia Utama

Muhammad Syafi'i Antonio, 2001, Bank Syariah dari Teori ke Praktik, Jakarta, Gema Insani

Muhammad Ibn Ahmad Ibnu MuhammadIbn Rusyd, Bidayatul Mujtahid wa Nihayatul Muqtasyid, Beirut, Darul Qalam, , vol II

Nurul Huda, Mohamad Heykal, 2010, Lembaga Kenangan Islam, Tinjauan Teoritis dan Praktis, Jakarta, Kencana

PP Muhammadiyah, 1971, Himpunan Putusan Majelis Tarjih Mubammadiyah, Cetakan III, Yogyakarta, Sumber Jaya Bandung

Shalah ash Shawi dan Prof Dr. Abdullah al Mushlih, 2011, Fikih ekonomi keuangan Islam, Jakarta, Darul Haq,

Setiawan Budi Utomo, 2003, Fiqih Aktual, Jawaban Tuntas Masalah Kontemporer, Jakarta, Gema Insani Press

Sukmadi, 2010, Pengantar Ekonomi Bisnis, Bandung, Humaniora Utama Press

Yusuf Qardhawi, 1995, Fatwa-fatwa Kontemporer, Jilid II, Jakarta, Gema Press Insani, J 